\title{
Self, Sin, and the Sacred: Some Elements of a Select Psychology for the Care of Souls
}

\author{
Rein Nauta
}

Published online: 22 July 2008

(C) The Author(s) 2008

\begin{abstract}
Many pastors feel that their work in the secular sphere can best be described as an exploration of the meaning of life: as spiritual care. However, the idea that it is possible and easy to find such a thing as "the meaning of life," as well as the concurrent idea that this meaning will help to make life more agreeable, should not be taken for granted but, rather, should be considered to be open for further exploration. To get a better understanding of the difference between spiritual care and the care of souls, I will discuss three central themes in any pastoral practice: sin, sense, and sorrow, together with three related constructs: soul, self, and the sacred. My exposition will result in a plea for revaluing two traditional but ever relevant modes of religious leadership: the modes of shepherd and teacher, of tutor and theologian, which are performed either in the context of the church or the secular institutional environment.
\end{abstract}

Keywords Self $\cdot$ Sin $\cdot$ Soul $\cdot$ Identity $\cdot$ Religious leadership

\section{Introduction}

Many church ministers feel attracted to what can be characterized as a relatively more mundane form of chaplaincy, as carried out in hospitals, prisons, schools or other secular institutions. They feel themselves more in tune with a job description wherein their work is defined as being related to an exploration of the meaning of life, and wherein they direct themselves towards those who are in crisis and have lost any sense of purpose in and understanding of their existence. These ministers prefer to define their professional expertise in terms of the provision of spiritual guidance. They leave the parochial ministry not just because they prefer a more secular institution above an ecclesiastical environment, but also because they feel attracted to the more topical character of the task to be performed. They are experts in providing meaning and finding sense in the daily routines of

R. Nauta $(\bowtie)$

Department of Religious Studies and Theology, University of Tilburg, P.O. Box 90153,

5000 LE Tilburg, The Netherlands

e-mail: R.Nauta@UvT.nl 
the clients and patients whom they assist in exploring the meaning of life. Whereas the minister's task grows evermore diffuse, the duties of those who provide spiritual care are well defined and appear to be more adapted to the existential needs of modern men and women. Whereas a minister of the church is ordained for the care of souls, professionals in spiritual care just attend to the spiritual aspects of being. Notwithstanding an articulate job description, whereby the institutional chaplain is designated as a provider of professional help and support in circumstances where the meaning of one's existence becomes less than self-evident, it might be fruitful to analyze the differences in perspective with those who still try to define their ministry as the care of souls.

I intend to analyze these differing perspectives by exploring the meaning of three terms that are key to understanding any ministry: sin, sense, and sorrow, as amplified by some observations about soul, self, and suffering. Central to my argument in the discussion that follows is the idea that if the pastoral profession is to be salvific, some notion of the impact of the cultural and religious context of our society is necessary. The discussion will end in a plea for the care of souls as a theological calling and a pedagogical profession.

\section{Self and the meaning of life}

Human beings search for meaning in all they do and in all that happens to them: they want to believe that it all makes sense. But no formula is able to answer in a sufficient and satisfactory degree the question why? The American philosopher Robert Nozick (1981) illustrates the sheer conceit of many propositions by presenting them dialogically in all their pretension: "The meaning of life is to seek union with God-oh yeah, that one. A meaningful life is a full and productive life - sure. The purpose of life is to pursue the task of giving meaning to life - thanks a lot. The meaning of life is love-yawn. The meaning of life is spiritual perfection - the upward and onward trip" (p. 573).

Happily enough, the need to find the meaning of life is, in the daily course of existence, not that urgent. Most of the time the question of meaning is answered implicitly by doing what has to be done. People bring order into their lives by polishing their shoes, by washing up the dirty dishes, by going to work on time (Berendsen 2002). It is the ordinary that gives meaning to life, the habit that breeds security, the feeling of being safe at home. When looking back at the years of one's childhood, life presents itself as a paradise of self-evident existence. Birthdays were celebrated according to a strict pattern of festivity, holidays marked the regularity of daily life. A common culture with its inherent and implicit rules and regulations - this is the way things are done - confirms the value of an every-day world that could be taken for granted. The meaning of it all was not in question, because everything was as it was and as it was it was fine, otherwise it would have been different.

This childish feeling of faith in what is disappears when we lose the ability to trust in the predictability of life, when life loses its trustworthiness. The world becomes strange when children become strangers to themselves, when their own bodies and being become problematic. This is the stage in life when boredom spreads. Young adolescents have no taste anymore for what used to be amusing or even exhilarating, because now they have to make sense of an existence that has lost its self-evident meaning. Previously one complied with what already existed, but now the adolescent is forced to find a position; what used to be taken as given has changed into a matter of choice. The young person becomes paralyzed by this increased freedom. Freedom should be used, yes, but how and when and why? The freedom of choice and action finds its apotheosis in a fundamental paradox: the freedom to choose who one wants to be. The question of meaning thus appears to be most 
characteristically an issue of puberty and adolescence. The question of meaning is first and foremost, a search for an individual identity: the question, essentially, of: "who am I?"

The search for identity is a real quest. Although one is the son of these parents, lives in that street, attends this school, the real person is always in excess of these constituting elements. The question of authenticity - the real me - is as impossible to answer as that about the meaning of everything. The answer to the question about the real me is always problematic, because uncertainty and distance are core characteristics of being human.

People are able to look at themselves and make inquiries about who they are. They can say $I$ and at the same discuss themselves as me: "I am not certain who I am, I find it difficult to talk about myself, I hope you will give me some support." As they are strangers to themselves, it is not surprising that a kind of strangeness also characterizes their relationships with other people. This feeling of strangeness and estrangement is magnified when one realizes that others are not all equal, and that in relation to each of those "others" one behaves differently (Werff 1985). The language used when talking with one's parents is different from that spoken with friends or with colleagues. Not only the grammar, but also the substance and semantics of the words used fit the specific relationship existing between partners in dialogue. But if this is true, is it not also the case that the person speaking invariably assumes a different persona in each particular discourse? Perhaps people are not only strangers to themselves but also a different person in each and every relationship.

But then what about authenticity? Authenticity can only exist as a choice. The choice a person makes about who they want to be is a real choice, if made in good faith. To convince others, however, one has to behave in congruence with the expectations those others have regarding the consequences of that choice. To be real, and to make others believe in that reality, one has to conform to what is expected and perceived as right. Authenticity may be like a game: it should be played according to the rules in order that others will say that's just like the real thing.

\section{Sin and soul}

But perhaps all these social-psychological frivolities do more to obscure the tragic condition of one's existence than to enlighten and alleviate the problem of sense and self, of meaning and identity. In general, it is possible to say that the more people have freedom to choose, including for whom they want to be, the more difficult it is for them to determine who they really are. As a result, it is very seductive to remain a child forever, with all opportunities still open, without any commitment, believing that choices are not necessary. Such an ideal of everlasting childhood, of eternal adolescence, seems to be an idiosyncratic feature of the modern era. When one's sense of identity is threatened by everyday stresses and strains, it is preferable to believe in grandiose fantasies instead of succumbing to the dreary facts of insufficient performance and lack of ability. In such circumstances it is more agreeable to escape to idealized romances than to commit oneself "for better and worse" to a stable relationship, let alone to marriage (Satinover 1987). However, a failure to adapt to external circumstances, as evidenced by unrealistic romantic expectations and too farfetched ideals, is not the main problem of adolescence, or even of adulthood. The core pathology of the Puer Aeternus is his inability to take the measure of his own strengths and forces. When a powerful self is lacking, when the inner life is empty and depleted, then the world outside is perceived as over-charged: others must be constantly available to lend support and consolation, and are requested to provide the affirmation that can not be found when one is left to oneself. 
The wish to remain a child, to flee the obligations of adulthood, is strengthened in a society in which people are reduced to a childlike state. Although in an individualized society the person appears to be of central importance, the single individual is, at the same time, reduced to nothing more than a number in a bureaucratic conglomerate, is made uncertain about safety and care wherever public institutions have been privatized, and is made to feel insecure about his pedagogical proficiency in order to be made dependent on the models and norms set by professional educators. The resulting loss of self-esteem makes the person indifferent to the fate of others. This indifference, however, does not mean independence, owing to an enduring need for praise and laudation and sensitivity to the appraisals and judgments of others. Consequently, any capacity for empathy is lacking, while respect for who one is, or tries to be, is sought from anyone who one, even if it is just fleeringly, meets. In such a culture of narcissism (Lasch 1979), which is the mental counterpart of an individualized society, the individual person does not feel endangered by any sense of guilt about what has been done wrong, but, rather, is menaced by the anxiety of being a nobody.

In a narcissistic culture, sin seems to be without relevance or meaning. Nevertheless, an analysis of the concept of sin, and in particular the evaluation of the eight deadly sins, can contribute to a better understanding of the tragic alienation of modern man (Capps 1987, 1989, 1990, 1992, 1993; Capps and Cole 2000, 2006; Derckx 2006; Nauta 2002; Nauta and Derckx 2007). Beliefs about the importance of the deadly sins are still consistent with a theology of guilt but the personal experience of these sins is better explained by the dynamics of shame.

The results of a research project conducted among students of theology in Tilburg, the Netherlands, in 2002, and repeated on a larger scale among pastoral and therapeutic professionals in 2003 (Derckx 2006; Nauta and Derckx 2007) are more or less equivalent to those reported in a study conducted in the USA (Capps 1989, 1992, 1993). The most deadly sins are held to be lust and melancholia, but the personal sins, those sins personally committed, are pride and envy. Donald Capps interpreted these results as evidence for the burden of narcissistic vulnerability. Envy is the sin with which these students struggle the most, they are jealous of others who receive the recognition they want for themselves, as is signified by the personal importance of pride. Pride and envy are the sins of a vulnerable self, of a narcissistic necessitous ego. The respondents wished that they did not need the admiration of others, but felt unable to deny that impulse. Envy and pride express the desire for empathy and support, for recognition and admiration, all of which the respondents sadly missed. These sins are typical of "losers" in the struggle for life. A certain consciousness of the longing to be respected and admired and of the disappointment that follows when this is not the case, may be taken as a warning against lapsing into the even greater sin of melancholia: the feeling of being lonely and alone, abandoned by God and man, with bitterness that makes life inhospitable and feeds despair.

In 2002, a different picture of sin developed, one that, unfortunately, is in line with the results found in the replications of Capps \& Cole's original study $(2000,2006)$. What was to be feared has become reality. Although lust is still considered to be the worst sin, melancholia - bitterness - is now the sin that most of the respondents feel they themselves have committed. Thirty percent of the respondents experience melancholia as the real, personal $\sin$ in their lives. They feel they have been wronged in life, that they have not received what they considered, in all reasonableness, as their due. These results present the dominant feeling in our culture, typified by: a sense of the negation of the individual person, of the want of an appreciation of basic needs of security and care, of health and freedom, in a society that was never before as rich and prosperous as it is today, and of the 
lack of vision and perspective in a culture in which a vulgar market ideology appeared to express the highest political wisdom. The results of the questionnaire about the deadly sins are the more appalling because they reflect the opinions and feeling of an intellectual avantgarde: adult students who, after having experienced the plights and joys of a primary career, have chosen for a theological curriculum in order to sharpen and deepen their insights into the dynamics of the lived faith in a world that has become more and more secularized: a choice that has given them, as they themselves say, a profound personal satisfaction.

Melancholia appears to reflect a more general embarrassing feeling of uneasiness and discomfort. That feeling seems to express a fundamental failure of self-esteem, a loss of any sense of a whole and healthy self. Sigmund Freud (1917/1975) analyzed the psychological origins of such a depressive feeling of self loss. Melancholia is like mourning. Both are reactions to an experience of loss: the loss of a loved one. The melancholic feels himself to be the victim of a deliberate act of abandonment. This feeling cannot be openly acknowledged because the act of abandonment denies the reciprocity of the love relationship. The resentment and rage against the lover by whom one has been left turns, therefore, against the melancholic himself. Depression, loss of self esteem, doubt and anger can not be expressed because it is not easy to acknowledge that one is in mourning over a loved one who did not love the mourner in return. This putative lover can be a person (a dead or adulterous husband), but also an institution (the church that became too strict or too loose, politics that were based on the wrong ideology, society which did not provide the care and security that were expected), an idea that disappointed (Christian faith, Marxism) or an employer (forced retirement may sometimes cause a form of melancholic mourning). Melancholiacs feel that they have been hurt in the core of their being, in the heart of their existence. They feel as though they have lost their souls. At the same a vital and ultimate concern is introduced into their lives: an ardent desire for meaning and a fervent hope to make sense of what has happened.

\section{Sorrow and the sacred}

Appropriate and relevant to this situation of alienation and depletion is the practice of the care of souls. Even if that care is provided by pastors and ministers who themselves suffer the sorrows of a culture caught in confusion and bewilderment. Those whose profession is the care of souls are connected with the center of existence in stead of being focused on just one aspect of it, namely, that of the spiritual. They feel called to help ground an existence in which any fundament is lacking and to suggest a perspective that will illuminate the darkness that encapsulates the poor, wretched soul. The care of souls, more so than spiritual care, is a privilege of the church. Spiritual care, as provided in hospitals, in the military, in schools and many other secular institutions is always considered to be an aspect-discipline, in conjunction with physical, educational or psychological care. Those who provide spiritual care may or may not be ordained ministers of the church. In many cases their performance is evaluated for its relevance and effect by the management of the institute that pays their salary. Where a doctor has to heal the ailments of the body, the professional who provides spiritual care is expected to provide a remedy for the pathologies of the spirit. Or at least to provide a sufficient help to ensure that spiritual problems will not interfere with such medical, judicial, educational, or military procedures and processes as are characteristic of the institution's model of an able, moral, educated person. In these institutions spiritual care is foremost functional in re-establishing a person's fitness for their assigned role in a successful therapy, sentence or training. In most of the cases it is 
understood that spiritual suffering is detrimental to success. Therefore spiritual care is always taken to be a cure just to remedy spiritual needs and problems (cf. Nauta 2003b). The care of souls, however, is concerned with the whole person albeit from a particular perspective: that of the relationship between creature and Creator. The concept of the soul is necessarily correlated to the idea of the sacred. Grace and redemption are the sole solace for the inevitable sorrows of life, which pester the human being for whose tragic fate no cure exists, other than a capacity to believe that is grounded in faith. Bishops, ministers, lay elders, the church leadership in genera, exercise their duties within this perspective as defenders of the faith. They can fulfill their ministry, which in ultimo is no less than the care of souls, in two capacities: as shepherd/pastor and tutor/teacher, as theologian and pedagogue.

\section{Pastor and pedagogue: a liturgy of shame}

One is made pastor by those who pour out their troubles and wait for a word of compassion and deliverance. In all sorts of different ways people try to find some release from the chaos of daily living. They project their anxieties and fantasies upon others in order to find some appearance of control in a disturbing and alarming situation. Leaders and helpers are then burdened with the responsibility of finding a solution for otherwise unsolvable problems (Meindl et al. 1985; Bion 1959). When they accept that role, they become illusionists who make what is real to forget but help to instill hope for a better life to come (Klein 1948; Nauta 2003a). Such processes are imminent to the relationship between therapist and client, leader and follower, pastor and parishioner, shepherd and sheep. Feelings projected onto the therapist, because they are too painful for the patient himself to bear and are therefore repressed, are received, contained and exposed - mentally digested, as it were - by the therapist. In the process, these feelings loose some of their unbearable heaviness and can once again fit within the patient's mental world (Ypma 2001). By talking about these feelings, by showing how to discuss them as though they belong to somebody else, those feelings can be taken back and accepted because words provide the necessary distance and space for their reception.

Neither the psychotherapist nor the pastor has to be perfect in playing the role of container. Perhaps a little failure and a small imperfection in providing sufficient support are necessary to be of actual help. It is not the thoroughly empathic, always accepting and always understanding pastor but, rather the pastor who is but all too conscious of his own failures, doubts, frustrations, disappointments, aversions and prejudices, who may be best able to surmise and work through all those hidden and repressed anxieties and fears, and in doing so care for the soul. Here the pastor acts primarily as pedagogue. In such a confrontation, of stupid and dumb, but talkative, seekers and witnesses, as once on the way to Emmaus, some consciousness and acceptation of imperfection may result, however slowly. Paradoxically this may be the necessary condition for the renewal of a life that appeared to have been lost.

When we feel worthless, without anything to be proud of, the desire for affirmation and recognition, and for somebody who will nevertheless say a good word or bring us glad tidings, is great. In this context of support, images may be even more important than words, while in the dumbness of shame gestures may be more telling than loosely uttered phrases. In a liturgy of shame therefore the blessing is the central ritual element. When ashamed, we want to hide from the critical eyes of knowing others, but blessed we are seen and accepted for whom we are. When blessed we receive grace and peace (Num. 6: 22-27; cf. Ruiterkamp 1988). The blessing is a gesture full of symbolical connotations. It recalls the mother who holds you against her body and protects you, it recalls the father who stands 
behind you and encourages you to dare and persevere. The blessing as a gesture may also be seen as a sign of surrender, of vulnerability, of equality between those who are blessed and those who perform the act of blessing. Such gestures are healing to those who have lost themselves.

Tutor and theologian — a theology of shame

In our times a theology of guilt is less relevant than a theology of shame. Who feels guilty anymore? Guilt has to do with choosing the wrong alternative out of a multitude of possible options. Guilt has to do with what has been done in stead of who one is. Guilt is partial. Shame on the other hand is concerned with the ideal ego instead of the moral self: the super ego. Shame is related to an ideal of who one wants to be. Shame is an all-encompassing emotion, caused by some trivial pursuit that does not fit into the picture of the ideal self. When guilty, one can try to make amends but, when ashamed, one is caught in silence, becoming mute, and dumb, unable to speak about the why and wherefore of shame. To confess that one is ashamed just ameliorates the shame. Shame cannot be redeemed. Ashamed one wants to hide from the pubic eye. Shame is related to the cognition that one is not the person one wished to be, and is expressive of a tragic alienation, both from ourselves and from all those who are near to us. A theology of shame should speak about loneliness and isolation, of abandonment and secrecy, of failure and shortcomings. In the biblical tradition there are many moments in which such loneliness is experienced as God-forsaken solitude, from Adam and Eve to Jesus and Judas.

Such crises show how life lacks harmony and cohesion. These attacks on the self make life fragmentary, unfinished, disrupted; such that it does not make sense. At the same time the experience of the fragmentary shows how life is set towards wholeness. The meaning of a fragment is made clear in the context of the esthetical (Luther 1991). Fragments refer to what is unfinished, that did not come off, broken. Unfinished may mean both what was originally whole and perfect-the torso, the ruin, to fragments from the past, but also refer to what is not yet finished, what is in preparation, what may be, life is a scaffold for the future too. Fragments refer: they stimulate a search for the wholeness that they themselves are missing and that cannot be found in them. The notion of the fragmentary may be foundational for providing any meaning in our lives.

As such, fragments are essential to the care of souls. The capacity for love, for care, presupposes the notion of the fragmentary. Understood as fragment we are insufficient in ourselves and are dependent on others. The care of souls is not a therapeutic discipline directed towards adaptation to an alienated existence, but a theological exercise in humanity. As a theologian the minister active in the care of souls may be considered to be a tutor unto Christ (cf. Stendahl 1976). When the soul is cared for, the so eagerly believed façade of order and harmony is broken down. The care of souls exposes the strangeness of our existence. The comfort given by those who care for the soul is that everything is out of order, that we live in chaos and hell (Luther 1998). The message delivered is not very arousing or exiting. What remains is to participate in the sorrows, the discomfort and disconsolateness of one another, to walk away from where life had the appearance of happiness and joy. Caring for the soul implies mourning about disappointed expectations, about opportunities missed, about flops and failure; however, in doing so, hope is maintained and life restored.

Although for many disappointed and frustrated ministers a professional function in spiritual care appears to be attractive as a solution for their own feelings of alienation, my argument may convince them that the care of souls in particular, which requires solidarity in 
fate, will reinstate their pride in the ministry they perform. Caring for the souls of those who are wandering without any destiny and are depressed by the sorrows of an existence without any sense of purpose or meaning, allows them to act as both pastor and pedagogue, as tutor and theologian. The leadership of the church is provided by these two Christian ministries of old.

Open Access This article is distributed under the terms of the Creative Commons Attribution Noncommercial License which permits any noncommercial use, distribution, and reproduction in any medium, provided the original author(s) and source are credited.

\section{References}

Berendsen, D. (2002). Oprecht veinzen, echt geloven. In de Marge, 11, 38-43.

Bion, W. R. (1959). Experience in groups. London: Tavistock.

Capps, D. (1987). Deadly sins and saving virtues. Philadelphia, PA: Fortress Press.

Capps, D. (1989). The deadly sins and saving virtues: How they are viewed by laity. Pastoral Psychology, $37,229-253$.

Capps, D. (1990). Sin, narcissism, and the changing face of conversion. Journal of Religion and Health, 29, 233-251.

Capps, D. (1992). The deadly sins and saving virtues: How they are viewed by clergy. Pastoral Psychology, 40, 209-233.

Capps, D. (1993). The depleted self. Sin in a narcissistic age. Minneapolis, MN: Fortress Press.

Capps, D., \& Cole, A. H. (2000). The deadly sins and saving virtues: How they are viewed today by laity. Pastoral Psychology, 48, 359-376.

Capps, D., \& Cole, A. H. (2006). The deadly sins and saving virtues: How they are viewed today by clergy. Pastoral Psychology, 54, 517-534.

Derckx, L. G. M. (2006). Wrok \& begeerte. Een pastoraal-psychologisch onderzoek naar de praktijk van hoofdzonden in een cultuur van narcisme. Budel, The Netherlands: Damon.

Freud, S. (1975). Trauer und Melancholie. In A. Mitscherlich, A. Richards \& J. Strachey (Hgs.), Sigmund Freud Studienausgabe, Band 3. Psychologie des Unbewuszten (pp. 193-212). Frankfurt am Main: Fischer Verlag.

Klein, M. (1948). Contributions to psychoanalysis, 1921-1945. London: Hogarth Press.

Lasch, Chr. (1979). The culture of narcissism. American life in an age of diminishing expectations. New York: Warner Books.

Luther, H. (1991). Leben als Fragment. Der Mythos der Ganzheit. Wege zum Menschen, 43, 262-273.

Luther, H. (1998). Die Lügen der Tröster. Praktische Theologie, 33, 163-176.

Meindl, J. R., Ehrlich, S. B., \& Dukerich, J. M. (1985). The romance of leadership. Administrative Science Quarterly, 30, 78-102.

Nauta, R. (2002). Echte en erge zonden: Een inleiding. In R. Nauta, (Red.). Over zonde en zonden. Opstellen over de tragiek van het bestaan (pp. 7-14). Nijmegen, The Netherlands: Valkhof Pers.

Nauta, R. (2003a). The performance of authenticity: Ordination and profession in pastoral care. Pastoral Psychology, 51, 425-431.

Nauta, R. (2003b). Zin, zorg en zonde. Enkele aspecten van een psychologie van de geestelijke leiding. Praktische Theologie, 30, 318-328.

Nauta, R., \& Derckx, L. G. M. (2007). Why sin? A test and an exploration of the social and psychological context of resentment and desire. Pastoral Psychology, 56, 177-188.

Nozick, R. (1981). Philosophical explanations. Cambridge, Mass.: Harvard University Press.

Ruiterkamp, G. (1988). Gezegend ben je! Een studie van achtergrond, vorm en functie van de Aaronitische zegen (Numeri 6:22-27). Groningen, The Netherlands: Rijksuniversiteit, Faculteit der Godgeleerdheid.

Satinover, J. (1987). Science and the fragile self: The rise of narcissism, the decline of God. In D. M. Levin (Ed.), Pathologies of the modern self. Postmodern studies on narcissism, schizophrenia, and depression (pp. 84-113). New York: New York University Press.

Stendahl, K. (1976). The apostle Paul and the introspective conscience of the West. In K. Stendahl (Ed.), Paul among Jews and Gentiles, and other essays (pp. 78-96). Philadelphia, PA: Fortress Press.

Werff, J. J. van der (1985). Identiteitsproblemen: Zelfbeschouwing in de psychologie. Muiderberg, The Netherlands: Coutinho.

Ypma, S. (2001). Tussen God en gekte: Een studie over zekerheid en symbolisering in psychose en geloven. Den Haag, The Netherlands: Boekencentrum. 